\title{
Diagenetic features and porosity dense evolution of Chang 8 tight sandstone reservoir in Hujianshan area, Ordos Basin
}

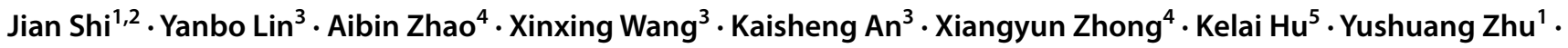 \\ Linyu Liu ${ }^{1}$
}

Received: 11 September 2020 / Accepted: 9 January 2021 / Published online: 17 February 2021

(c) The Author(s) 2021

\begin{abstract}
Diagenesis is the main reason for tight reservoir lithology, complex pore-throat structure, strong heterogeneity, and variable occurrence and distribution characteristics of fluid in the pore-throat, which directly restricts the Chang 8 oil layer group in the Ordos Basin. Exploration and development. Based on the analysis of a large number of cores and thin slices, through the application of scanning electron microscopy, high-pressure mercury intrusion and other experimental testing methods, the diagenesis characteristics of the Chang 8 tight reservoir in the Hujianshan area of the Ordos Basin and the mechanism and process of tight porosity evolution are analyzed in depth. The relationship between different diagenetic facies belts, pore structures and their impact on reservoir quality is further explored. The results show that the Chang 8 reservoir in the Hujianshan area is in the mid-diagenetic stage A, which mainly experienced compaction-pressure dissolution, cementation, dissolution and other diagenesis. The compaction caused the loss of a large number of primary pores in the sandstone, which is the most important factor for the densification of the Chang 8 reservoir in the study area, followed by cementation of carbonate and clay minerals. The chlorite clay film formed in the early diagenesis retained the primary particles. The inter-pores maintain good reservoir physical properties, and are affected by the acidic diagenetic environment. The unstable feldspar minerals dissolve. The dissolution pores produced effectively improve the connectivity and permeability of the pores. The compaction reduces the porosity on average by $19.37 \%$ and the loss rate reaches $51.86 \%$. The cementation reduces the porosity on average by $11.97 \%$ and the loss rate reaches $32.66 \%$. The dissolution increases the porosity by $3.26 \%$ on average. In the process of pore evolution, the compaction of the early diagenetic stage $\mathrm{A}$ and the authigenic clay minerals and carbonate cementation in the middle diagenetic stage are the main reasons for the substantial decrease in porosity. The early diagenetic stage B is due to its short duration. Less porosity is lost. The secondary pores generated in the early diagenetic stage A are basically filled with microcrystalline calcite, while the organic acid dissolution in the middle diagenetic stage is limited. According to different diagenetic minerals and pore evolution characteristics, combined with logging response characteristics, the whole area is divided into four diagenetic facies. Among them, the residual chlorite-membrane intergranular-pore facies and the feldspar dissolution facies of chlorite film are the most favorable diagenetic facies. The findings of this study can help for better understanding of the diagenetic characteristics and quantitative evolution of pores, reveal the diagenetic-pore evolution rules of Chang 8 sandstone reservoirs in the study area, and provide a basis for reservoir evaluation and prediction in the study area.
\end{abstract}

Keywords Diagenesis $\cdot$ Pore evolution $\cdot$ Diagenetic facies $\cdot$ CHANG 8 reservoir $\cdot$ Hujianshan area $\cdot$ Ordos basin

\section{Introduction}

Yushuang Zhu

642617295@qq.com

Extended author information available on the last page of the article
The tight sandstone reservoir has become a hot topic of research into the oil and gas resources (Zou et al. 2012; Dai et al. 2012). The Ordos Basin, one of the major tight reservoirs in China, is endowed with gigantic volumes of oil and gas reserves resulting from the composite tightening processes involving sedimentation, diagenesis and tectonic 
movements (Reed et al. 2005; Hood et al. 2003). The original texture of the reservoir rocks was governed by sedimentary environments and sedimentary factors, sedimentary systems, microfacies, and petrographic properties of sediments affect the consolidation of sandstone reservoirs and the types of authigenic minerals(Gould et al. 2010; Paxton et al. 2002; Ajdukiewicz and Lander 2010; Dutton et al. 2012). While the reworking effects of different diageneses on the physical properties of a reservoir varied in the course of burial evolution. Generally mainly three factors that affect the pore structure during burial diagenesis: (1) Compaction is a physical and chemical process controlled by depositional texture, detrital composition, and burial history(Dou et al. 2018). (2) Cementation is governed by source materials, fluid flow and pressure-temperature history (Berger et al. 1997; Taylor et al. 2010). Excessive growth of quartz and excessive filling of authigenic clay minerals severely damage primary porosity (Anjos et al. 2003; Berger et al. 2009; Weibel et al. 2010). The authigenic chlorite coating enhances the compressive strength of the rock and protects the primary pores by inhibiting the precipitation of quartz, but this coating inhibits the leaching of the coated feldspar by organic acids (Schnaid et al. 2001; Saidi et al. 2003; Spinelli et al. 2007; Anjos et al. 2003). (3) Although dissolution increases the pore space, if there is no large-scale mass transport, the porosity improvement is limited because the dissolution of unstable minerals is present in the nearby pore space with new diagenetic minerals. Therefore, the degree of improvement of pore space in the dissolution process is limited, mainly leading to the redistribution of porosity and the change of pore throat geometry (Giles and Marshall 1986; Bjørlykke and Jahren 2012). In general, diagenesis is controlled to some extent by the sedimentary system of the reservoir that profoundly shaped its pore textures, which is considered to be the primary cause of extremely complicated pore-evolution history (Wang et al. 2017).

Chang 8 reservoir in the Triassic Yanchang Formation of Hujianshan area (Fig. 1) is the major pay horizon of the investigated area. The reservoir is generally tight and is in close contact with high-quality hydrocarbon source rocks of the Chang 7 reservoir. The crude oil from the target reservoir is predominantly light oil (with the density of less than $0.85 \mathrm{~g} / \mathrm{cm}^{3}$ in most cases). According to the definition and identification criteria of the tight oil (Jia et al. 2012), the crude oil from the target reservoir falls into the category of tight oil (Zou et al. 2012; Yao et al. 2013). The tightness feature has become a major problem that hinders further exploration of tight oil in the target area. Many scholars have shed light on diagenetic and pore-evolution histories of the Upper Triassic Yanchang Formation in the Ordos Basin (Xi et al. 2015; Zhong et al. 2013; Liao et al. 2014; Shi et al. 2018). Yet most of the research only briefly describes the sedimentary environment and diagenesis of the target reservoir, but fails to reach deeper into the differentiated diagenetic features of the reservoir and their influence on the pore evolution (Zou et al. 2008). Such diagenetic features, as an immediate, comprehensive result of clastic compositions, natures of interstitial materials, pore-throat structures and evolutionary history, are of great significance to future exploration actions toward the target reservoir (Ceriani et al. 2002; Fu et al., 2013; Zhu et al. 1992; Chen et al. 1994). Compared with previous studies, this time we conducted an in-depth analysis of the main influencing factors of reservoirs in the Hujianshan area, including diagenetic evolution characteristics, porosity recovery, and diagenetic facies division. The research level of the study area was also changed

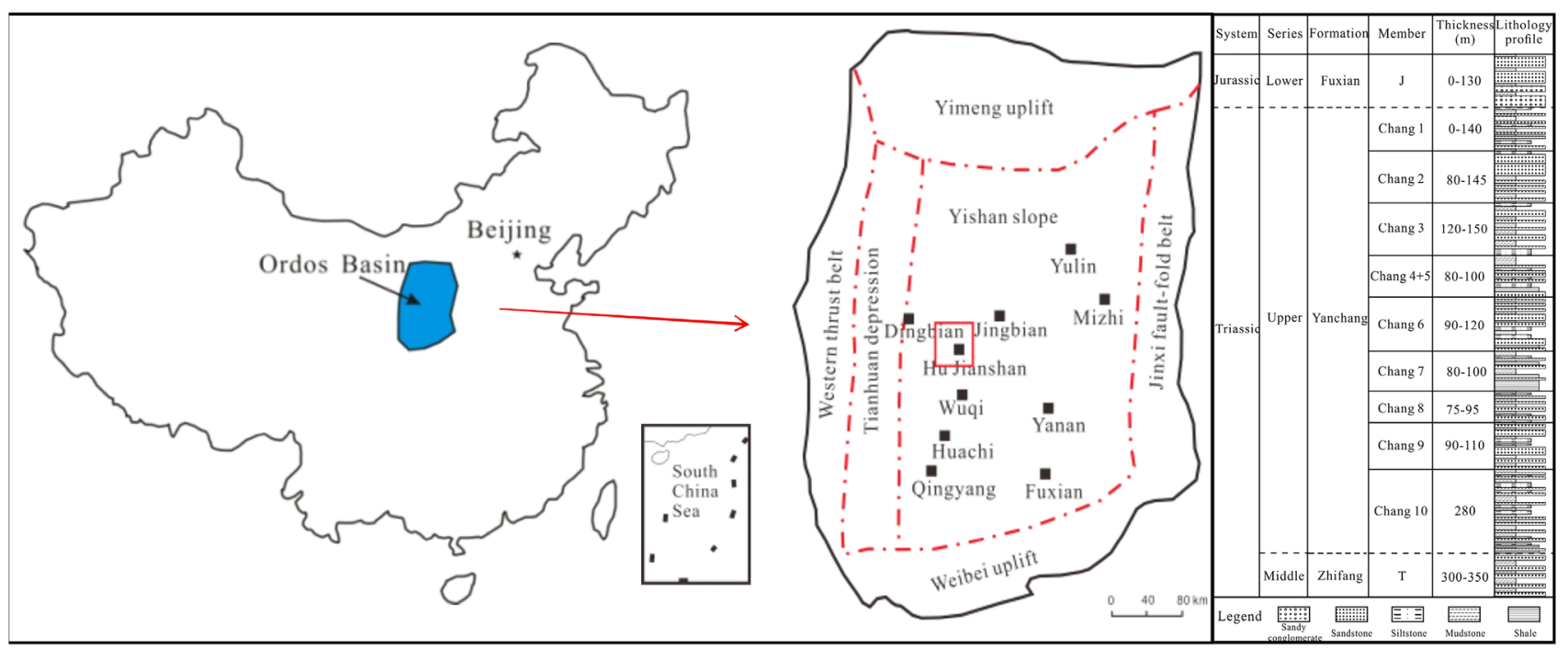

Fig. 1 Geographical location of Hu Jianshan Oilfield in the Ordos Basin

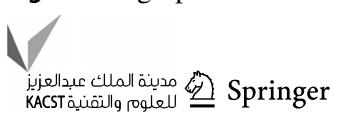


from qualitative and rough to quantitative. The diagenesis characteristics and quantitative evolution of the pores of the Chang 8 tight sandstone in the Hujianshan area of the Ordos Basin were studied through experimental tests such as core physical property analysis and description, cast thin sections, scanning electron microscopy and cathodoluminescence, and the pores of the Chang 8 reservoir in the Hujianshan area were established. Degree evolution simulation equation, quantitative recovery of porosity, clarification of diagenesis and pore evolution rules. Additionally, this paper will further divide diagenetic facies based on logging responses, and predict the horizontal distribution pattern of the diagenetic facies, in order to facilitate explorative actions to the tight reservoir in the investigated area and provide some theoretical basis for future exploration.

\section{Regional geological background}

The Ordos Basin is a depressed Mesozoic continental lake basin on the North China Craton. The chronostratigraphical composition of the Ordos Basin includes marine deposits before the early Permian epoch at the bottom, transitional facies between the early Permian epoch and the mid-late Triassic epoch in the middle, and continental deposits at the top predominantly. The stratigraphic composition of this area is basically intact, with only strata of the Silurian and the Devonian systems and the Lower Carboniferous Series in absence. The Yanchang Formation of the Upper Triassic Series (T3y) and the Yan'an Formation of the Lower Jurassic Series (J1y) are the most prospective Mesozoic oil-bearing series in the basin. T3y contains a 1,000 m 1,100 m-thick inland lake-basin deposit of mostly clastic rocks, where 10 individual reservoirs, i.e. Chang 1 to Chang 10 from top down, are harbored, presenting the entire evolution history of the lake basin(Fig. 1). Among these reservoirs, Chang 9, Chang 7, Chang 5 and Chang 4 are mainly composed of black mud shale, while the rest predominantly composed of interstratified sandstone, siltstone and greyish-green mudstone. A large-scale Zhangjiatan shale in Chang 7 right in the center of the culminated lake basin is the major Mesozoic hydrocarbon source rock series of the entire reservoir. Below it is Chang 8, generally featuring low porosity and low permeability, which is perfect for the downward migration of oil and gas from the maturely evolved high-quality hydrocarbon source rocks of Chang 7, creating typical tight oil at Chang 8.

Hujianshan area in the mid-west Ordos Basin is tectonically a simply structured monocline gently dipping west at a dip angle of $0.4^{\circ} \sim 0.6^{\circ}$ inside the Yishan Slope, neighboring the Tianhuan Source Depression, with an exploration coverage of $3,260 \mathrm{~km}^{2}$ (Liao et al. 2010). The Yanchang Formation inside the investigated area is mainly distributed with depressed inland lake delta deposits(Liu et al. 2012), which from top to bottom, is divided into 10 reservoirs, i.e. Chang 1 to Chang 10, according to the distribution of lithology and sedimentary cycles. Among them, Chang 7 to Chang 10 show signs of lake basin expansion, which culminates at Chang 7 in the depositional stage, and then, converges all the way up gradually from Chang 6 to Chang 2, until declining to peneplanation at Chang 1(Li et al. 2012; Liao et al. 2012; Lai et al. 2013). The target reservoir Chang 8 is predominantly distributed with shallow-water delta sedimentary systems, primarily including subfacies of deltaic plains and deltaic fronts. The tightness feature of the target reservoir is the major problem that hinders the progress of the exploration efforts.

\section{Samples and methods}

For this study, lots of drilling, logging and analytical data were collected in Hujianshan. 50 pieces of core samples were taken based on description graphs of cores at a depth of $650 \mathrm{~m}$ from 35 wells. Each sample is cylindrically shaped, $2.5 \mathrm{~cm}$ in diameter and $5 \mathrm{~cm}$ in length. Conventional physical properties analyses were performed on all 50 samples. Some of the samples were milled into thin sections to perform casting thin section analysis, aiming to typologically investigate the minerals, diagenesis and pores; and to perform the SEM analysis, aiming to morphologically and typologically investigate the pores and authigenic clay minerals. Among these samples, 41 typical pieces were taken for HPMI analysis to figure out the types and natures of the pore-throat structures; among them 35 best pieces were picked out to acquire the contents of different minerals and the surface porosity of different pore types, by means of point-counting (at least 350 points per thin section). On such basis, granularity analyses were carried out to acquire the sorting coefficient and original porosity of the sandstone.

Optical microscopes, including Leica DMRXHC and Linkam THMSG600, were employed in this study to observe the $15 \mathrm{~mm} \times 15 \mathrm{~mm}$-sized and 0.03 -mm-thick casting thin sections. The FEI Quanta 650FEG SEM was also used to acquire sample information by scanning the sample surface with electron beams. Micromeritics's AutoPore IV9510 mercury porosimeter, with a maximum operating pressure of $414 \mathrm{MPa}$, was used for HPMI, enabling to measure the pore-throat radius in a range from $0.003 \sim 1,000 \mu \mathrm{m}$.

\section{Basic reservoir characteristics}

The sandstone of the Chang 8 reservoir is mainly composed of fine-grain lithic feldspar sandstone and feldspar lithic sandstone (Fig. 2), featuring tight texture with a low average

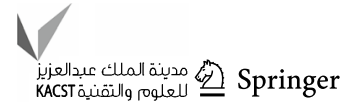




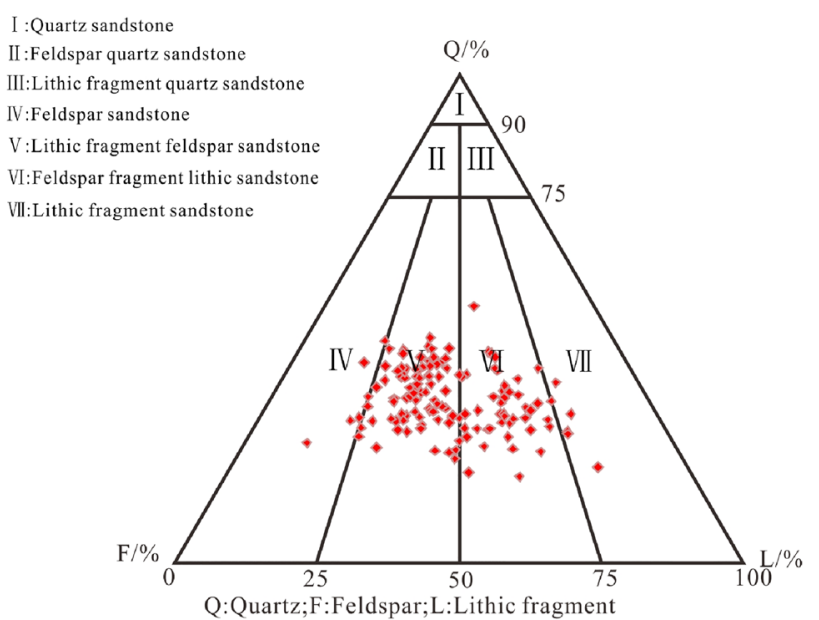

Fig. 2 Sandstone components and type of Chang 8 reservoir in $\mathrm{Hu}$ Jianshan area

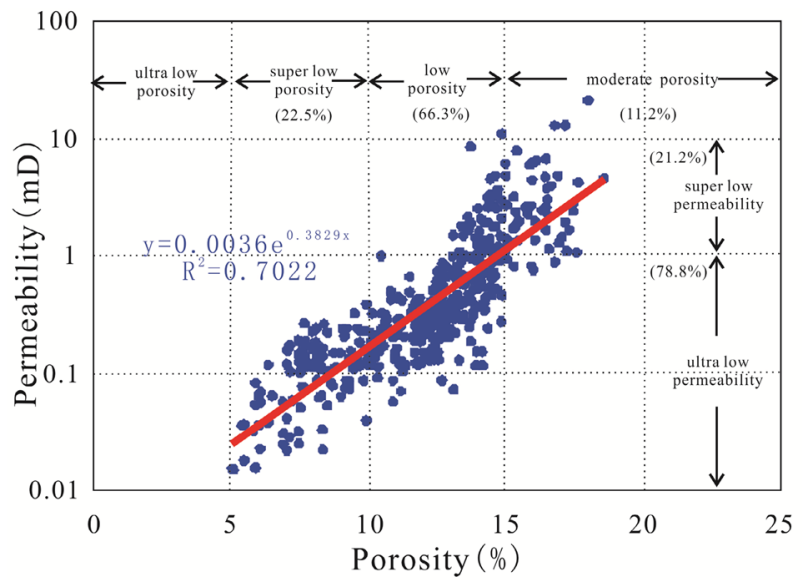

Fig. 3 Relationship between porosity and permeability of Chang 8 reservoir in $\mathrm{Hu}$ Jianshan area porosity of $11.3 \%$ and an ultra-low average permeability of $0.86 \times 10^{-3} \mu \mathrm{m}^{2}$ (Fig. 3). The reservoir is highly heterogeneous, predominantly composed of intergranular pores $(61.4 \%)$ and dissolved feldspar pores $(26.3 \%)$. The pore radius is unevenly distributed, and small and micro pores dominate. The content of interstitial materials is $14.2 \%$ on average, mainly ferrocalcite $(7.4 \%)$, followed by illite $(2.9 \%)$, chlorite $(2.3 \%)$ and kaolinite $(1.7 \%)$. The general sorting quality of the sandstone is moderately fine, with its psephicity mainly being subangular shapes, mostly presenting in the way of porous cementation with moderate structural maturity. Intergranular contacts are mainly linear ones.

The HPMI test performed on 41 samples taken from the target Chang 8 reservoir suggests an average displacement pressure of $1.36 \mathrm{MPa}$, a maximum pore-throat radius of $1.42 \mu \mathrm{m}$, and a median pore-throat radius of $0.33 \mu \mathrm{m}$. The pore-throats are relatively small and predominantly composed of ultra-small pores and micro-fine throats, presenting relatively poor physical properties. The capillary pressure curve is basically an oblique line, where the gentle section appears unclear at a high level with a corresponding sorting coefficient of 2.2 on average, suggesting the poor sorting level and high heterogeneity of the pore-throats in the target reservoir. The maximum average mercury injection saturation is $76.3 \%$, while the mercury ejection efficiency appears at a rather low level of $30.9 \%$ on average, suggesting a relative large volume of the non-mercury-saturated microthroats and poor permeability of the target reservoir at the maximum mercury injection pressure.

The porous structures of the investigated area is henceforth divided into four types, i.e. Types I, II, III and IV, according to the HPMI parameters and corresponding capillary pressure curves (Table 1 and Fig. 4).

The Type I reservoir is mainly composed of microfine and medium throats, with its capillary pressure curve appearing in the lower left of the chart, where the curved

Table 1 Statistics of Pore Structure Parameters by Regular Mercury Injection in Chang 8 reservoir in Hujianshan area

\begin{tabular}{|c|c|c|c|c|}
\hline Classification parameters TMTM & $\begin{array}{l}\text { Type I } \\
\text { Range }\end{array}$ & $\begin{array}{l}\text { Type II } \\
\text { Range }\end{array}$ & $\begin{array}{l}\text { Type III } \\
\text { Range }\end{array}$ & $\begin{array}{l}\text { Type IV } \\
\text { Range }\end{array}$ \\
\hline Porosity/\% & $10.8 \sim 18.2$ & $9.4 \sim 14.1$ & $6.5 \sim 12.4$ & $6.2 \sim 10.4$ \\
\hline Permeability $/ \times 10^{-3} \mathrm{um}^{2}$ & $0.26 \sim 1.67$ & $0.07 \sim 1.53$ & $0.03 \sim 1.0$ & $0.01 \sim 0.87$ \\
\hline Displacement pressure/MPa & $0.1 \sim 1.04$ & $0.33 \sim 2.91$ & $2.3 \sim 5.32$ & $>4$ \\
\hline Pore throat radius/urn & $0.36 \sim 3.18$ & $0.17 \sim 1.86$ & $0.03 \sim 0.82$ & $<0.2$ \\
\hline Sorting coefficient & $1.1 \sim 2.5$ & $1.28 \sim 2.89$ & $1.8 \sim 3.0$ & $1.9 \sim 3.6$ \\
\hline MaximumMercury Saturation/\% & $78.7 \sim 93.9$ & $69.9 \sim 89.5$ & $59.8 \sim 87.3$ & $54.3 \sim 80.2$ \\
\hline Skewness coefficient & $-0.55 \sim 0.24$ & $-0.69 \sim 0.16$ & $-0.82 \sim 0.02$ & $-1.01 \sim 0.04$ \\
\hline Pore Structure & Intergranular pore & $\begin{array}{l}\text { Intergranular pore,feldspar } \\
\text { dissolved pores }\end{array}$ & $\begin{array}{l}\text { Feldspar is s olved, poresin- } \\
\text { tercrystalline pore }\end{array}$ & $\begin{array}{l}\text { Poresintercrys- } \\
\text { talline pore, } \\
\text { micropores }\end{array}$ \\
\hline Number of samples & 8 & 15 & 8 & 10 \\
\hline
\end{tabular}


section below $\mathrm{S}_{\mathrm{Hg}-50}$ appears in relatively slow slope with a low displacement pressure (of 0.10-1.04MPA, see Fig. 4a). The pore-throat radius mainly lies within a range of $0.36 \sim 3.18 \mu \mathrm{m}$, with a relatively small skewness of $-0.55 \sim 0.24$ and a sorting coefficient of $1.1 \sim 2.5$ (1.7 on average). The maximum mercury injection saturation ranges between $78.7 \%$ and $93.9 \%, 87.5 \%$ on average. The permeability is mainly contributed by fine- and medium-sized throats sized between $0.1 \sim 2 \mu \mathrm{m}$. Around $72.6 \%$ of the total effective throat volume is taken up by throats sized over $0.1 \mu \mathrm{m}$, while those sized $0.32 \sim 1.81 \mu \mathrm{m}$ contribute over $90 \%$ of the permeability (Fig. 4c), presenting the highest reserving capacity and permeability of the pore-throat structures among the entire reservoir.

The Type II reservoir is mainly composed of micro-fine and fine throats, with its capillary pressure curve similar to that of Type I, although its general displacement pressure $(0.33 \sim 2.91 \mathrm{MPa})$ is relatively higher (Fig. 4a). The porethroat radius mainly lies in a range of $0.17 \sim 1.86 \mu \mathrm{m}$ with a skewness of $-0.69 \sim 0.16$, which is basically in a normal distribution, and with a sorting coefficient of $1.28 \sim 2.89$, 2.00 on average. It appears with a higher maximum mercury injection saturation of $69.9 \% \sim 89.5 \%, 78.4 \%$ on average. Its permeability is mainly contributed by fine throats sized between $0.4 \mu \mathrm{m}$ and $3 \mu \mathrm{m}$. Those sized over $0.1 \mu \mathrm{m}$ contribute $58.2 \%$ of the total volume of effective movable throats; those sized $0.25 \sim 1.2 \mu \mathrm{m}$ provide over $90 \%$ of its permeability (Fig. 4d), suggesting a relatively inferior reserving capacity and permeability to Type I.

The Type III reservoir is mainly composed of micro-fine throats. Its capillary pressure curve is slightly inclined to the upper right of the chart, where the curved section below $\mathrm{S}_{\mathrm{Hg}-50}$ fluctuates drastically, suggesting a higher displacement pressure (2.30 5.32 MPa) than the previous two types (Fig. 4a). The pore-throat radius of Type III mainly lies between 0.03 and $0.82 \mu \mathrm{m}$, with a relatively small skewness of $-0.82 \sim 0.02$, and with a sorting coefficient of 1.8 3.0, 2.3 on average. The maximum mercury injection saturation of Type III $(59.8 \% \sim 87.3 \%, 73.2 \%$ on average $)$ is lower than that of the previous two types. Its permeability is mainly contributed by throats sized $0.3 \sim 0.7 \mu \mathrm{m}$. Those sized over $0.1 \mu \mathrm{m}$ take up approximately $53.6 \%$ of its total effective movable throat volume, while those sized $0.21 \sim 0.98 \mu \mathrm{m}$ contribute over $90 \%$ of its permeability (Fig. 4e), suggesting a mediocre performance in pore reserving capacity and permeability.

The Type IV reservoir is mainly composed of absorptive and micro-fine throats, with its capillary pressure curve tilting to the upper right of the chart with barely any leveling out, and the curved section below $\mathrm{S}_{\mathrm{Hg}-50}$ goes up at an even pace, with the highest displacement pressure (over $4 \mathrm{MPa}$ ) among all four curves (Fig. 4a). Its pore-throat radius mainly lies below $0.2 \mu \mathrm{m}$, with a fine skewness of $-1.01 \sim 0.04$, and with a sorting coefficient of 1.9 3.6, 2.7 on average. The maximum mercury injection saturation is $54.3 \% \sim 80.2 \%$ in this case, $63.5 \%$ on average (Table 3 ). Most of its permeability is contributed by pores sized around $0.01 \mu \mathrm{m}$. Those sized over $0.1 \mu \mathrm{m}$ take up around $33.7 \%$ of its total effective movable throat volume, and those sized $0.04 \sim 0.2 \mu \mathrm{m}$ contribute over $90 \%$ of its permeability (Fig. 4f), suggesting an invalid reservoir.

\section{Diagenetic features}

\section{Diagenetic types}

The Chang 8 reservoir has mainly experienced a series of diageneses, such as compaction- pressure solution, cementation, and dissolution, etc. Compaction is mainly of mechanical nature, as suggested by the linear intergranular contact under the microscope. Cement is mainly observed in clay minerals, carbonates and siliceous materials. Dissolution is mainly observed in feldspar. Both compaction and cementation appear in a destructive manner, while dissolution plays a constructive role in the reservoir (Wang et al. 2011; Pan et al. 2011; Chen et al. 2013).

\section{Compaction-pressure solution are destructive to primary pores}

The early stage of diagenesis, after sedimentation was completed, proceeded mainly by means of mechanical compaction; while pressure solution intensified during the middle and late diagenetic stages, meaning compaction occurs by different means and in different intensities at different stages. It is revealed that in the Chang 8 sandstone reservoir, the content of high pressure-strength minerals like quartz is low, while the content of weaker plasticlasts, like feldspar, lithic mudstone and particularly mica, is high. These plasticlasts experienced plastic deformation, hydrated dilation and alteration during the burial compaction, and pseudomatrix formed to squeeze into intergranular pores, resulting in clogging in the neighboring throats and a considerable loss of primary intergranular pores (Ma et al. 2013). Linear contact is observed in a predominant proportion in casting thin section samples under the microscope (Fig. 5a), and plastic deformations of lithic fragments and mica were found as well (Fig. 5b). Clearly, compaction is extensively developed in the investigated area and shows a medium-strong intensity in general.

\section{Cementation further damages pore space}

(1) Carbonate cementation Cementation of carbonates, as the primary cause of low porosity and low permeability,

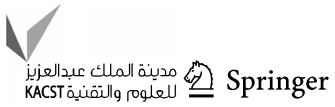



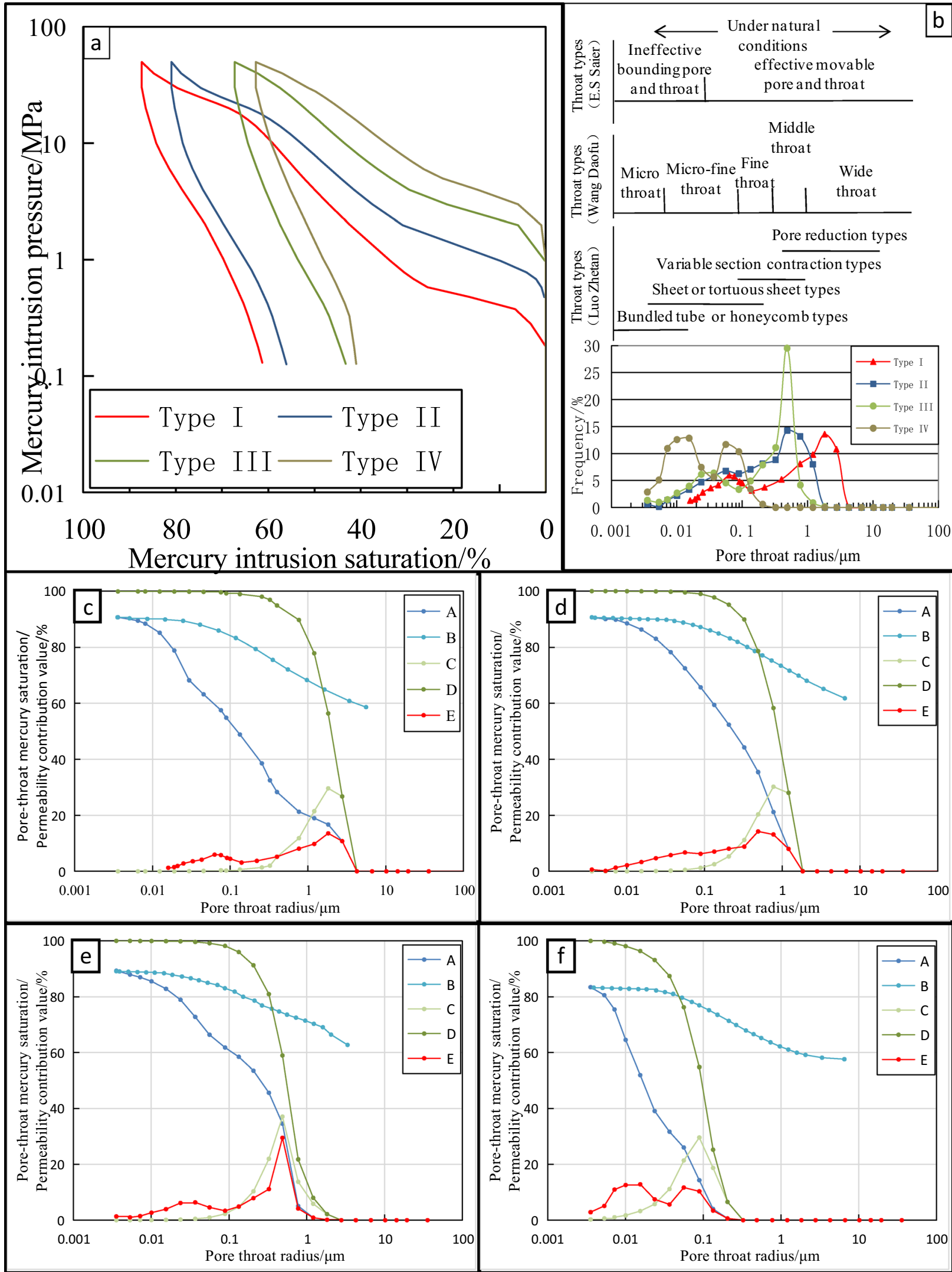
४Fig. 4 Different types of pore structure in Hujianshan area. (A-Cumulative mercury saturation;B-Ejection saturation;C-Permeability contribution value; D-Cumulative permeability contribution value;EPore-throat mercury saturation. a: Characteristics of high pressure mercury injection pressure curve; $\mathbf{b}$ : Distribution characteristics of pore throat radius; c: Type I; pore throat features of well $\mathrm{H} 23 \#$; d: Type II, pore throat features of well H2\#; e: Type III, pore throat features of well A296; f: Type IV, pore throat features of well H26\#)

was observed extensively in the Chang 8 reservoir in the investigated area where the cement includes ferrocalcite and small amount of calcite. Cementation of carbonates mainly appears in the manner of intergranular cements, metasomatic substances, or interstitial materials in dissolved pores. It usually appears to be microcrystalline, granular or intergrowing occurrences of different stages. Small amount of Fe-free micrite and microlitic calcite are found embedded in clastic particles or distributed in intergranular pores (Fig. 5c) in the early diagenetic stage. In the early mesogenetic stage, ferrocalcite took shape later than the chlorite membrane, but before hydrocarbon charging took place. Intergrowing accretion of ferrocalcite due to recrystallization is also observed, which appears with clear crystal surfaces and exists in intergranular pores or dissolved pores (Fig. 5d). In the middle to late mesogenetic stage, ferrocalcite with properly developed crystalline structures took shape after hydrocarbon charging took place, and filled in the remaining unsaturated pores, deteriorating the blockage of hydrocarbon seepage paths.

(2) Clay mineral cementation The clay minerals in the Chang 8 reservoir in investigated area mainly include kaolinite, chlorite and illite. Microscopic samples from the early diagenetic stage and early mesogenetic stage show kaolinite crystals in the shape of pseudo-hexagonal slabs, or appearing in page- or worm-shaped manners. These crystals exist in intergranular pores or in dissolved feldspar pores, where intercrystalline micropores are found as well (Fig. 5e). Kaolinite was generated mainly by means of feldspar alteration and corrosive sedimentation in the process of water-rock interaction, which took place before hydrocarbon charging, and then, turned into illite or chlorite in the middle and late diagenetic stages. Microscopic samples taken from the early diagenetic stage and the early mesogenetic stage are found with ctenoid chlorite wrapped up with clastic particles, which helps suppress the processes of water-rock interaction, secondary mineral enlargement and mechanical compaction, and appears in a brownish colour after being contaminated by the hydrocarbon inflow in the middle mesogenetic stage (Fig. 5f). Chlorite in the middle diagenetic stage is found to be filled pores in the shape of pompons under SEM (Fig. 5g). Illite mainly took shape in the middle diagenetic stage, which appears, under the microscope, attached to the surface of clastic particles or filling up the pore-throats, in scroll- and bridge-like shapes. Illite helps reduce the pore size and increase the tortousity of the throats (Fig. 5h).

(3) Siliceous cementation The siliceous cementation found in the Chang 8 reservoir in the investigated area mainly appears to be development of secondary enlarged fringes of quartz and authigenic quartz. Secondary enlarged fringes of Grade II and III are found on the fringe of quartz particles (Fig. 5i), yet rim cementation is seldom seen. Quartz enlargement occurs mainly due to reciprocal transformation with clay minerals and dissolution of carbonates, and subject to the size of available spaces as well, which makes it proliferating in sandstone reservoirs with small interstitial contents. The development of secondary enlargement fringe is not conducive to the preservation of intergranular pores as it usually takes up the clearance among particles. Enlargement fringe is also observed under SEM on chloritewrapped quartz particles where the chlorite membrane is not developed. Authigenic quartz crystals are usually found in intergranular pores with intact surfaces and clear edges (Fig. 5j).

\section{Dissolution contributes the forming of secondary pores}

Dissolution in the Chang 8 reservoir in the investigated area mainly appears in feldspar, yet the dissolution of carbonate cements is seldom seen, which may help improve the physical properties of the reservoir. Albite among the feldspar grains is more likely to be dissolved than the potassium feldspar, and the dissolution usually develops in a honeycomb-like shape along the cleavage cracks (Fig. 5k). Casting pores left by completed dissolved feldspar grains are found in some of thin sections under SEM, yet most of the pores have been partially or completely filled up by late-stage calcite minerals. Additionally, micro intercrystalline pores left by dissolved lithic particles are found locally (Fig. 51). In general, the dissolution of the target reservoir is at a medium level, with part of the dissolved pores filed by late-stage cements.

\section{Diagenetic evolution sequence}

The Chang 8 reservoir in the investigated area shows following diagenetic features: (1) Linear contacts in dominance among clastic particles, plus locally distributed concaveconvex contacts, presenting a medium-strong compaction; (2) Extensive quartz enlargement of Grade II and Grade III, distribution of authigenic quartz, and scarcely distributed feldspar enlargement and authigenic feldspar; (3) Extensive carbonate cementation, mainly ferrocalcite cements;(4) Extensive clay mineral cementation involving kaolinite, illite and chlorite, etc.; (5) Locally distributed interstitial

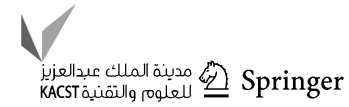




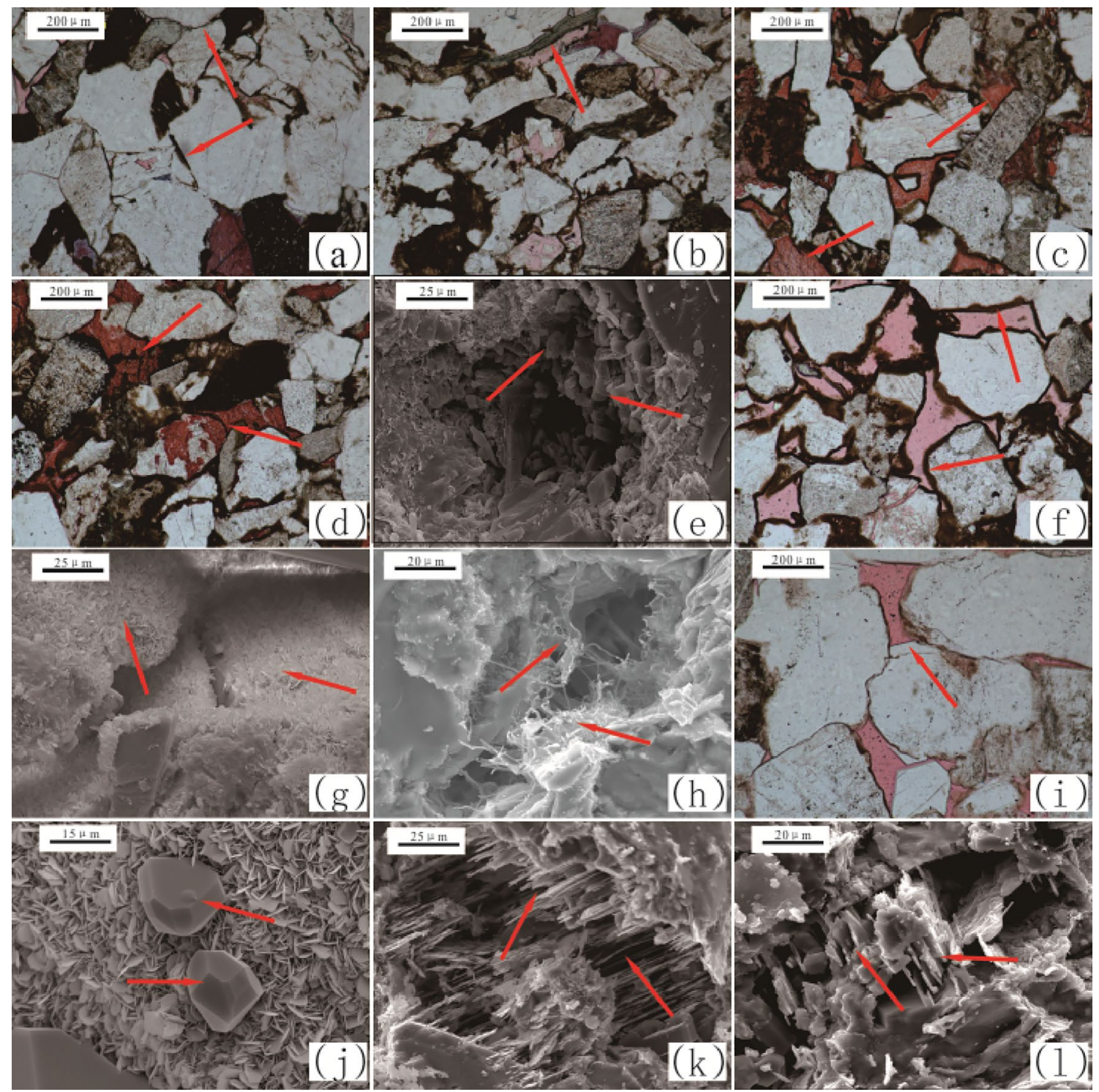

Fig. 5 Microscope figures of typical diagenetic phenomenons of samples of Chang 8 reservoir in Hu Jianshan area. (a: Granular linear contact; b: Plastic deformation of mica; c: Early-stage microlitic calcite-filled pores; $\mathbf{d}$ : Ferrocalcite-filled pores; e: Intergranular

asphalt or asphalt residues in pores, suggesting that organic substances have evolved to a mature level; (6) Extensive distribution of feldspar dissolution and scarcely distributed internal dissolution of ferrocalcite. Thus, it is concluded, according to the Chinese Dividing Standard for Diagenetic Stages in Clastic Rocks (SY/T5477-2033), the Chang 8 reservoir is currently at the mesogenetic stage A (Fig. 6).

\section{Influence of diagenesis on pore evolution}

Diagenesis played a crucial role in the physical property evolution and tightening process of the reservoir during the sedimentary burial evolution. The above-mentioned kaolinite-filled pores; f: Chlorite membrane; $\mathbf{g}$ : Pompon-like chlorite membrane-filled pores; $\mathbf{h}$ : Bridge-like illite; i: Secondary enlarged fringes of quartz; $\mathbf{j}$ : Authigenic quartz in intergranular pore; k: Feldspar dissolution; l: Lithic dissolution)

findings suggest that the porosity of the Chang 8 reservoir is influenced by compaction, cementation and dissolution with effects in a decreasing order. Quantitative analyses are therefore carried out on different diagenetic processes, after the porosity resulted from each process is calculated on premise of the reconstruction of the original porosity of the sandstone.

\section{Reconstruction of original porosity}

For the purpose of more accurate calculation of initial porosity, the current porosity and the quantitative change of porosity caused by compaction, cementation and dissolution, the 


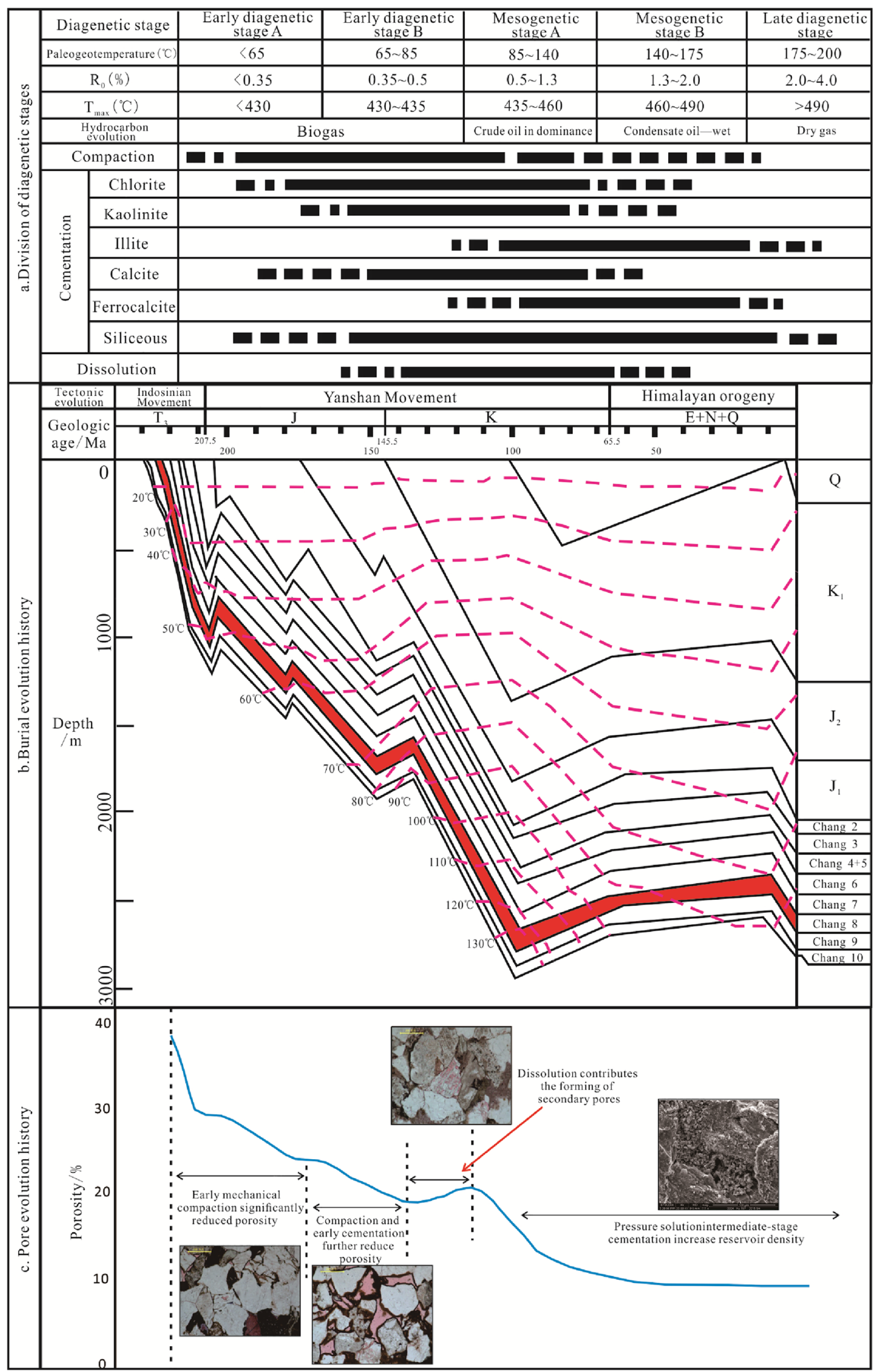

Fig. 6 Simulation of pore evolution of Chang 8 reservoir in Hu Jianshan area 
calculation formula and parameters of pore evolution are selected by experimental fitting method. (Beard and Weyl 1973; Athy 1930; Lenz 2002), via the following equation:

$\Phi 1=20.91+22.90 / S d$

where: $\Phi_{1}$ represents the original porosity of the unconsolidated sandstone (\%); $S_{d}$ represents the Trask sorting coefficient $S d=\sqrt{\frac{P 25}{P 75}}$ (in which $P_{25}$ and $P_{75}$ represent the corresponding granular diameter of $25 \%$-in-content particles and $75 \%$-in-content particles in the accumulative granularity curve respectively, in $\mathrm{mm}$ ). Granularity data suggest that the sorting coefficient of the Hujianshan area falls in 1.25-1.71, with an average of 1.45 ; the original porosity falls in $34.30-39.23 \%$, with an average of $37.24 \%$.

\section{Influence of compaction on porosity}

After original pores were subject to compaction-pressure solution in the early stage, some original pores were lost due to compaction, while some others were occupied by cement. Therefore, the porosity after compaction-pressure solution is the sum of the porosity of the residual intergranular pores and those occupied by cement in the early stage (Lenz et al. 2002; Ren et al. 2016). The post-compaction porosity $\Phi_{2}$ is thus calculated as below:

$\Phi 2=C+\frac{P 1+P 2}{P 4} \times P 3$

$P a=\Phi 1-\Phi 2$

$F a=\frac{P a}{\Phi 1} \times 100 \%$

where: $P_{1}$ represents the surface porosity of intergranular pores in $\% ; P_{2}$ represents the surface porosity of original micro pores in $\% ; P_{3}$ represents the measured porosity of the sample in $\% ; P_{4}$ represents the total surface porosity in \%; $P_{a}$ represents the porosity loss due to compaction in $\% ; F_{a}$ represents the ratio of porosity loss due to compaction in $\%$.

Calculation results (Table 2 and Fig. 6) suggest the porosity after compaction pressure solution falls in $8.46 \% \sim 29.4 \%, 17.87 \%$ on average; the ratio of compaction porosity loss falls in $26.8 \% \sim 77.4 \%, 51.86 \%$ on average. Clearly, the compaction pressure solution significantly reduced the original porosity, which is a major cause to the tightening of the reservoir.

\section{Influence of cementation on porosity}

Theoretically, the porosity loss due to cementation is approximately equal to the volume of cement. Therefore, the porosity after compaction and cementation is $\Phi_{3}=\Phi_{2-} C$, and the cementation-induced porosity loss is $P_{b}=C$. The ratio of porosity loss due to cementation is $F_{b}=\left(C / \Phi_{1}\right) \times 100 \%$.

Calculation results (Table 2 and Fig. 6) suggest the post-cementation remaining porosity falls in $2.8 \% \sim 9.3 \%$, with an average of $5.9 \%$. The ratio of porosity loss due to cementation falls in $12.1 \% \sim 51.6 \%$, with an average of $32.66 \%$. It is clear that the porosity is further reduced due to cementation.

\section{Influence of dissolution on porosity}

The dissolution changes the physical properties of the reservoir by creating numerous secondary pores from dissolved unstable substances like clastic particles and interstitial materials. The porosity gain contributed by dissolution is $\Phi_{2}=P_{5} \times P_{3} / P_{4}$, where $P_{5}$ represents the total surface porosity of the dissolved pores.

Calculation results (Table 2 and Fig. 6) suggest that the porosity after dissolution increases by $0.34 \% \sim 8.8 \%$, $3.26 \%$ on average. The reservoir of the investigated area, subject to compaction-pressure solution, and cementation, has become highly tight in the mid-late diagenetic stage, where the flow of organic acid was blocked and the dissolution was weakened. In addition, the dissolved pores of feldspar and lithic were partially blocked by carbonate cements, and the kaolinite generated by dissolution filled up the dissolved pores or piled up in the vicinity, which also deteriorated the physical properties of the reservoir. The additional secondary pores generated by the

Table 2 Porosity evolution in different diagenetic stages of typical samples of Chang 8 in Hu Jianshan area

\begin{tabular}{lllllll}
\hline Parameter type & $\begin{array}{l}\text { Primary } \\
\text { porosity } \phi 1, \\
\%\end{array}$ & $\begin{array}{l}\text { Post-compaction } \\
\text { porosity } \phi 2, \%\end{array}$ & $\begin{array}{l}\text { Post-cementation } \\
\text { porosity } \phi 3, \%\end{array}$ & $\begin{array}{l}\text { Dissolution- } \\
\text { enhanced porosity } \\
\phi 4, \%\end{array}$ & $\begin{array}{l}\text { Calculated } \\
\text { porosity On, } \%\end{array}$ & $\begin{array}{l}\text { Gasometric } \\
\text { porosity } P 3, \%\end{array}$ \\
\hline Chang 8 reservoir & $\max$ & 39.23 & 29.4 & 9.3 & 8.8 & 13.25 \\
& $\min$ & 34.3 & 8.46 & 2.8 & 0.34 & 4.38 \\
& average & 37.24 & 17.87 & 5.9 & 3.26 & 9.16 \\
\hline
\end{tabular}


dissolution, although limited in quantity, did improved the physical properties of the tight reservoir to some extent.

\section{Diagenetic facies and features}

A diagenetic facies is a result of multiple diagenetic effects working on the sediment in a certain diagenetic environment, which can be used to precisely anticipate the properties, scales and distribution of the reservoir in the investigated area; making it the focal point of researchers on reservoir and oil/gas exploration(Zou et al. 2008; Lan et al. 2014). In this study, the diagenetic facies are analyzed by means of single-factor analysis plus multi-factor integration (Deng et al. 2006), so as to specify the types of major diagenetic processes and features of pore evolution and development. Four types of diagenetic facies are defined for the Chang 8 reservoir in Hujianshan area depending on its sedimentary backgrounds, including the constructive facies, the residual chlorite-membrane intergranular-pore diagenetic facies and the feldspar-dissolution diagenetic facies; and the destructive diagenetic facies, clay-mineral-carbonate-cementation diagenetic facies and the mechanically tightened diagenetic facies. The former two diagenetic facies are featured with higher reservoir porosity and highly developed secondary pores, as well as the superior connectivity and permeability that make them the most prospective oil-bearing reservoirs. The latter two, in contrast, featured with low porosity, low permeability and narrow pore throats, due to the effects of compaction and cementation, resulting in inferior performance of the reservoir, as hydrocarbon migration into the pore space is insuperable under the capillary pressure during the transport process.

The strata information gathered by conventional logging includes various macro-physical properties, such as density, resistivity, hydrogen index, sound wave velocity, elementary/mineral composition, and granularity-related shale content, etc. The lithology and sedimentary environment of the reservoir can be revealed by means of conventional natural gamma logging; while density, interval transit time and neutron porosity logging are proven to be the most intuitive ways to represent the differences in physical properties of the reservoirs [33-35]. Therefore, the conventional logging data from different sequences can be used to identify the differences of diagenetic facies of the reservoir, so that the target reservoir can be divided into different diagenetic facies accordingly. The thin section data taken from the Chang 8 reservoir in the research area is analyzed to acquire its logging response characteristics of diagenetic facies; for this end, four types of strongly correlated logging curves, including natural gamma, density, interval transit time and neutron porosity, are picked out to establish the diagenetic facies of the entire logging area (Table 3,Fig. 7), and to provide an anticipation about the horizontal distribution of the diagenetic facies (Fig. 8).

\section{(1) Residual chlorite-membrane intergranular-pore diagenetic facies}

The diagenetic facies, under the influence of the sedimentary microfacies, is found primarily in the area favorable for the development of sedimentary microfacies within major underwater distributary channels at deltaic fronts (Fig. 8), where the cementation of the chlorite membrane played an constructive role to maintain the physical properties of the reservoir, as it helped improve the compaction resistance of the sandstone, and thus, helped keep the original intergranular pores basically intact [36]. The reservoir's physical properties are properly maintained, where Type I pore structures were extensively developed. Logging response data suggest a density below $2.49 \mathrm{~g} / \mathrm{cm}^{3}$, an interval transit time above $230 \mu \mathrm{s} \mathrm{m}^{-1}$, a neutron porosity over $20 \%$, and natural gamma reading below 80API, which are the signs of a favorable diagenetic facies with relatively higher permeability in an ultra-low-permeability reservoir. Such diagenetic facies, usually seen in the thick overlapping sands in multi-staged underwater distributary channels, are the most prospective oil-rich reservoirs, and also the most favorable diagenetic facies in the investigated area.

Table 3 Logging parameters of diagenetic facies of Chang 8 reservoir in Hu Jianshan area

\begin{tabular}{|c|c|c|c|c|}
\hline \multirow[t]{2}{*}{ Logging parameter } & \multicolumn{4}{|l|}{ Diagenetic facies } \\
\hline & $\begin{array}{l}\text { Residual chlorite-membrane inter- } \\
\text { granular-pore diagenetic facies }\end{array}$ & $\begin{array}{l}\text { Feldspar-dissolution } \\
\text { diagenetic facies }\end{array}$ & $\begin{array}{l}\text { Clay-mineral-carbonate-cemen- } \\
\text { tation diagenetic facies }\end{array}$ & $\begin{array}{l}\text { Tightly com- } \\
\text { pacted diagenetic } \\
\text { facies }\end{array}$ \\
\hline $\mathrm{DEN} / \mathrm{g} \mathrm{cm}^{-3}$ & $\leq 2.49$ & $\leq 2.51$ & $\geq 2.51$ & $\geq 2.52$ \\
\hline $\mathrm{AC} / \mu \mathrm{s} \mathrm{m} \mathrm{m}^{-1}$ & $\geq 230$ & $\geq 225$ & $\leq 218$ & $\leqq 210$ \\
\hline $\mathrm{CNL} / \%$ & $\geqq 20$ & $\geqq 18$ & $\leqq 18$ & $\leqq 19$ \\
\hline GR/API & $\leq 80$ & $\leqq 90$ & $\leq 100$ & $\leq 120$ \\
\hline
\end{tabular}




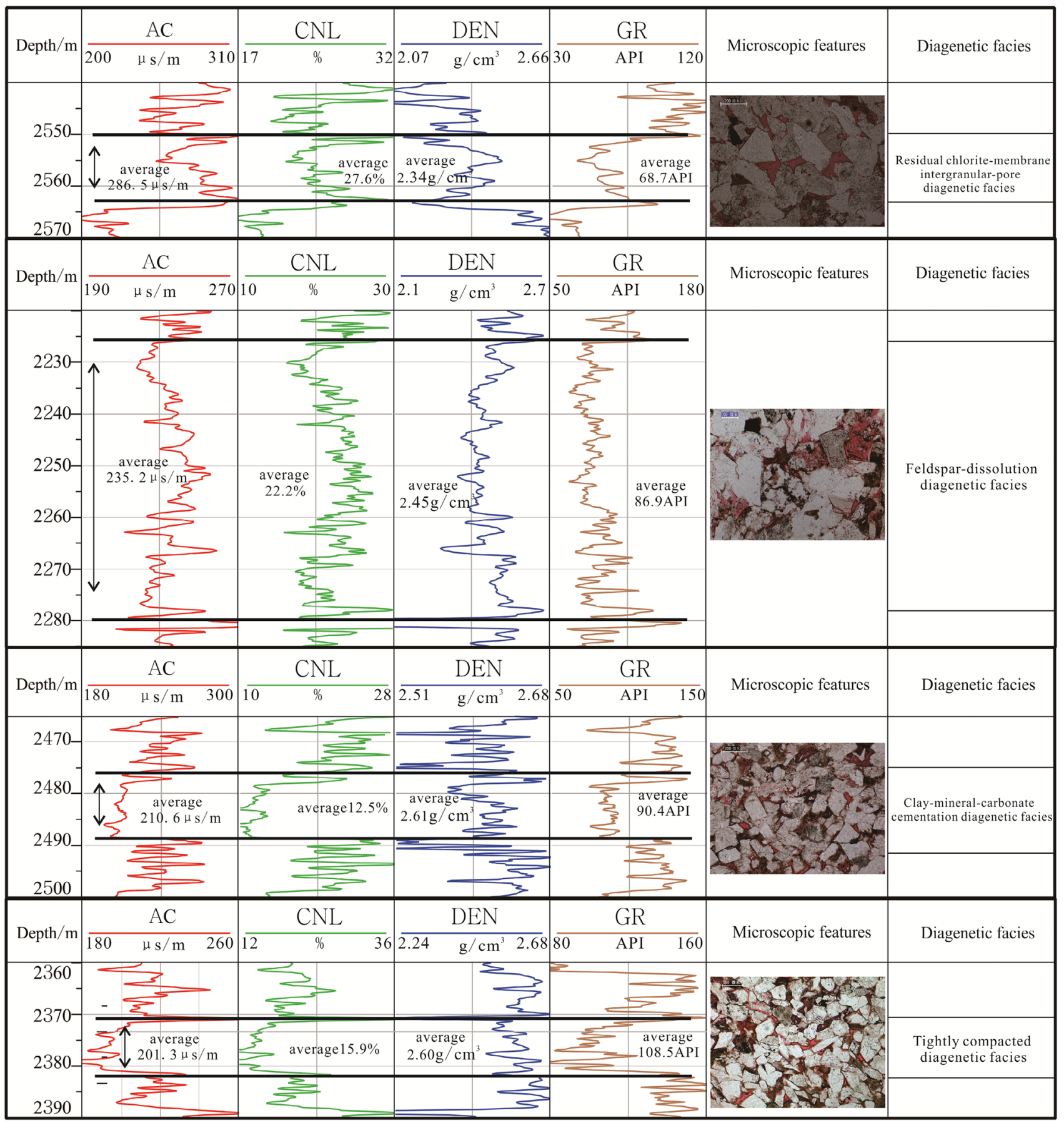

Fig. 7 Logging response characteristics of different diagenetic facies in the Chang 8 reservoir of in Hujianshan area. (Microscopic features:(1)Residual chlorite-membrane intergranular-pore diagenetic facies:Developed chlorite membrane-filled pores; (2)Feldspar-dissolution diagenetic facies:Feldspar dissolution-enhanced pore space;

\section{(2) Feldspar dissolution diagenetic facies.}

The diagenetic facies is found primarily in the area favorable for the development of sedimentary microfacies within underwater distributary channels at deltaic fronts (Fig. 8).
(3)Clay-mineral-carbonate-cementation diagenetic facies:Ferrocalcite and kaolinite-filled pores with metasomatic clasts and chlorite-filled pores; (4)Tightly compacted diagenetic facies:Tight intergranular contact, ferrocalcite-filled pores with small number of intergranular pores and micro-cracks)

In the late diagenetic stage, acidic fluids like organic acids and $\mathrm{CO}_{2}$ from source rocks flew into the sandstone and dissolved minerals like feldspar. The secondary pores caused by these acidic fluids enlarged the pore throats and effectively improved the connectivity and permeability of the 


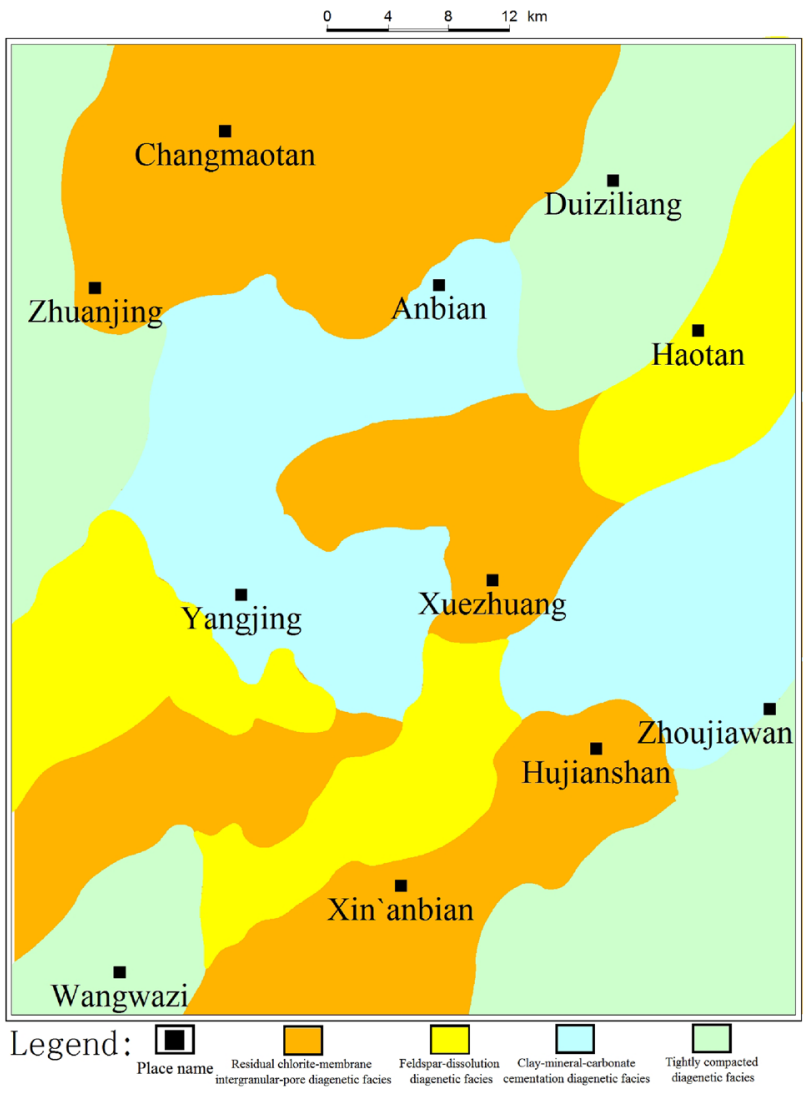

Fig. 8 Anticipated horizontal distribution of diagenetic facies of Chang 8 Reservoir in Hujianshan area. (1) Residual chlorite-membrane intergranular-pore diagenetic facies

pores, providing an average porosity of $10.3 \%$ and an average permeability of $0.52 \times 10^{-3} \mu \mathrm{m}^{2}$, where Type II pore structures were extensively developed. Logging response data suggest a density below $2.52 \mathrm{~g} / \mathrm{cm}^{3}$, an interval transit time over $225 \mu \mathrm{s} \mathrm{m}^{-1}$, a neutron porosity over $18 \%$, and a natural gamma reading below 90API. The diagenetic facies is proven constructive to the favorable reservoir and hydrocarbon accumulation.

\section{(3) Clay-mineral-carbonate-cementation diagenetic facies.}

The most extensively distributed forms of cementation in the Chang 8 reservoir are those of ferrocalcite and clay minerals, usually found on top and bottom of thick sands in deltaic distributary channels (Fig. 8). The sandstone of this diagenetic facies is usually in a dense texture, with massive pores filled up by clay minerals, and effective pores eliminated by ferrocalcite in tightened basal or porous cementation, producing a tightened porous combination that is unfavorable to the preservation of pores. The sandstone of this diagenetic facies presents poor reservoir quality, with an average porosity of
$7.8 \%$ and an average permeability of $0.26 \times 10^{-3} \mu \mathrm{m}^{2}$. Type III pore structures are in dominance, which can be taken to some extent as an invalid reservoir. Logging response data suggest a density above $2.51 \mathrm{~g} / \mathrm{cm}^{3}$, an interval transit time below $218 \mu \mathrm{s} \mathrm{m}^{-1}$, a neutron porosity below $18 \%$, and a natural gamma reading below 100 API.

\section{(4) Tightly compacted diagenetic facies}

This kind of diagenetic facies is mainly seen in shallow sands in underwater distributary channels and channel sides at deltaic fronts, as well as in sediment trap at distributary bays (Fig. 8), which is usually composed of mudstone, silty mudstone, and argillaceous siltstone, etc. The sandstone reservoir contains quite amount of plasticlasts like black mica, phyllite, and slate, and clastic quartz as well. Particles are mainly in linear or convex-concave contact that presents poor reservoir physical properties, and Type IV pore structures are predominant, which is barely available for a reservoir. The logging response data of the tightly compacted diagenetic facies, along with regional features, suggest a density over $2.52 \mathrm{~g} / \mathrm{cm}^{3}$, an interval transit time below $210 \mu \mathrm{s} \mathrm{m}^{-1}$, a neutron porosity below $19 \%$, and a natural gamma reading over 110 API.

\section{Summary and Conclusions}

1) The Chang 8 reservoir in Hujianshan oilfield is a tight sandstone reservoir featuring ultra-low porosity and ultralow permeability, mainly composed of lithic feldspar sandstone and feldspar lithic sandstone. After compaction-pressure solution, cementation and dissolution, currently the reservoir is in the mesogenetic stage A. Mechanical compaction is the primary cause of its tightening, and cementation works the same way with less effectiveness. The early stage chlorite clay membrane is extensively developed and maintains massive primary intergranular pores, which present favorable reservoir physical properties. Unstable minerals like feldspar were subject to dissolution in the acidic environment, which led to dissolved pores that expanded the reservoir space and improved the inter-pore connectivity.

2) The original porosity of the sediments is $37.24 \%$, which is reduced by $19.37 \%$ on average due to the effect of sedimentary compaction, resulting in $51.86 \%$ of porous space loss. The porosity is further reduced by the effect of cementation by $11.97 \%$ on average, resulting in $32.66 \%$ of porous space loss. Dissolution contributes $3.26 \%$ of the porosity increment on average. These diagenetic sequences and porosity evolution parameters quantitatively represent the difference of porosity evolution at different diagenetic stages and the indicative function of reservoir exploration and development. 
3) The diagenetic facies of the investigated area is identified as per different diagenetic processes and sedimentary backgrounds. Four major diagenetic facies are identified in the Chang 8 reservoir, and logging response features are gathered as well to provide a plan of diagenetic facies division for the entire area. Among the four diagenetic facies, the tightened diagenetic facies and the carbonate-cementation diagenetic facies are destructive to the development of the reservoir for their inferior physical properties and microporous structures; while the feldspar-dissolution diagenetic facies and the residual chlorite-membrane intergranular-pore diagenetic facies are considered constructive to the development of the reservoir space for their favorable physical properties and porous structures. The latter two diagenetic facies are crucial to the generation of high-quality reservoirs.

Acknowledgments This work is funded by National Major Science and Technology Projects of China (2017ZX05013004); National Natural Science Foundation of China(41702146,41802166, 51874242); China Postdoctoral Science Foundation (2018M643554).

Funding Funding was provided by National Major Science and Technology Projects of China (Grant No. 2017ZX05013004), China Postdoctoral Science Foundation (Grant No. 2018M643554), National Natural Science Foundation of China (Grant Nos. 41702146, 41802166, 51874242).

Open Access This article is licensed under a Creative Commons Attribution 4.0 International License, which permits use, sharing, adaptation, distribution and reproduction in any medium or format, as long as you give appropriate credit to the original author(s) and the source, provide a link to the Creative Commons licence, and indicate if changes were made. The images or other third party material in this article are included in the article's Creative Commons licence, unless indicated otherwise in a credit line to the material. If material is not included in the article's Creative Commons licence and your intended use is not permitted by statutory regulation or exceeds the permitted use, you will need to obtain permission directly from the copyright holder. To view a copy of this licence, visit http://creativecommons.org/licenses/by/4.0/.

\section{References}

Ajdukiewicz JM, Lander RH (2010) Sandstone reservoir quality prediction: the state of the art. AAPG Bull 94:1083-1091

Anjos SMC, De Ros CMA, Silva, (2003) Chlorite authigenesis and porosity preservation in the Upper Cretaceous marine sandstones of the Santos Basin, offshore eastern Brazil. Clay mineral cements in sandstones. Int Assoc Sedimentol Spec Publ 34:291-316

Athy LF (1930) Density, porosity and compaction of sedimentary rocks. AAPG Bull 14:1-24

Beard DC, Weyl PK (1973) Influence of texture on porosity and permeability of unconsolidated sand. AAPG Bull. 57:349-369

Berger G, Lacharpagne JC, Velde B, Beaufort D, Lanson B (1997) Kinetic constraints on illitization reactions and the effects of organic diagenesis in sandstone/shale sequences. Appl Geochem 12:23-35

Berger A, Gier S, Krois P (2009) Porosity-preserving chlorite cements in shallow-marine volcaniclastic sandstones: evidence from
Cretaceous sandstones of the Sawan gas field, Pakistan. AAPG Bull 93:595-615

Bjørkum PA, Oelkers EH, Nadeau PH, Walderhaug O, Murphy WM (1998) Porosity prediction in quartzose sandstones as a function of time, temperature, depth, stylolite frequency, and hydrocarbon saturation. AAPG Bull 82:637-648

Bjørlykke K, Jahren J (2012) Open or closed geochemical systems during diagenesis in sedimentary basins: constraints on mass transfer during diagenesis and the prediction of porosity in sandstone and carbonate reservoirs. AAPG Bull 96:2193-2214

Ceriani A, Giulio AD, Goldstein RH (2002) Diagenesis associated with cooling during burial: an example from Lover Cretaceous reser-voir sandstones. AAPG Bull 86:1573-1591

Chen Y, Liu Y (1994) Diagenetic facies-a new approach to the prediction of reservoir rocks. Exp Petroleum Geol 16:274-281

Chen Z, Zhu Y, Chen X (2013) Sedimentation and diagenesis of Chang 82 reservoir in the Yanchang Formation in Jiyuan region Ordos Basin. Oil Gas Geol 34:685-693

Dai J, Ni Y, Wu X (2012) Tight gas in China and its significance in exploration and exploitation. Petroleum Explor Dev 39:257-264

Deng Y, Ji H, Wu Y (2006) Single factor diagenetic facies analysis of tight reservoir in western Sichuan foreland basin. Acta Petrolei Sinica 27:48-52

Dou W, Liu L, Wu K, Xu Z, Liu X, Feng X (2018) Diagenetic heterogeneity, pore throats characteristic and their effects on reservoir quality of the Upper Triassic tight sandstones of Yanchang Formation in Ordos Basin China. Mar Pet Geol 98:243-257

Dutton SP, Loucks RG, Day-Stirrat RJ (2012) Impact of regional variation in detrital mineral composition on reservoir quality in deep to ultradeep lower Miocene sandstones, western Gulf of Mexico. Mar Pet Geol 35:139-153

Fu J, Wu S, Fu J (2013) Research on quantitative dia-genetic facies of the Yanchang Formation in Longdong Area Ordos Basin. Earth Sci Front 20:86-97

Giles MR, Marshall JD (1986) Constraints on the development of secondary porosity in the subsurface: re-evaluation of processes. Mar Pet Geol 3:243-255

Gould K, Pe-Piper G, Piper DJW (2010) Relationship of diagenetic chlorite rims to depositional facies in Lower Cretaceous reservoir sandstones of the Scotian Basin. Sedimentol 57:587-610

Hood SD, Nelson CS, Kamp PJJ (2003) Modification of fracture porosity by multiphase vein mineralization in an Oligocene nontropical carbonate reservoir Taranaki Basin, New Zealand. AAPG Bull. $87: 1575-1597$

Jia C, Zou C, Li J (2012) Assessment criteria, maintypes, basic features and resource prospects of the tight oil in China. Acta Petrolei Sinica 33:343-350

Lai J, Wang G, Chen M (2013) Pore structures evaluation of low permeability clastic reservoirs based on petrophysical facies: A case study on Chang 8 reservoir in the Jiyuan region Ordos Basin. Pet Explor Dev 40:566-573

Lan Y, Deng X, Cheng D (2014) Diagenetic facies and reservoir quality evaluation of Chang 6 sandstone reservoir in the upper Triassic Yanchang Formation of Huaqing area, Ordos Basin. Acta Petrologica et Mineralogica 33:51-63

Lenz SC (2002) Subcritical crack growth in creep compaction experiments. Texas A\&M University. School of Geosciences, Texas, pp 21-48

Li X, Liu X, Zhou S (2012) Hydrocarbon origin and reservoir forming model of the Lower Yanchang Formation Ordos Basin. Pet Explor Dev 39:172-180

Liao P, Tang J, Pang G (2012) Reservoir characteristics and control factors of Chang $8_{1}$ of Yanchang Formation of Triassic in Jiyuan region of Ordos Basin. J Mineral Petrol 32:97-104

Liao P, Wang Q, Tang J (2014) Diagenesis and porosity evolution of sandstones reservoir from Chang 8 of Yanchang formation in 
Huanxian-Huachi region of Ordos basin. J Cent South Univ (Sci Technol) 45:3200-3210

Liao Y, Zheng R, Wang C (2010) Analysis of high-resolution sequence stratigraphy in Chang-8 subsection of Yanchang Formation, Jiyuan Area of Ordos Basin. Acta Sedimentol Sin 28:481-488

Liu H, Wang J, Liu Q (2012) Favorable reservoir distribution and its controlling factors of the Chang 8 interval of Upper Triassic Yanchang Formation in Jiyuan Area, Ordos Basin. J Palaeogeography $14: 285-294$

Ma H, Zhou L, Zhang X (2013) Diagenesis and favorable diagenetic facies of Chang8 reservoir in Jiyuan area of Ordos Basin. Pet Geol Exp 35:378-383

Pan G, Liu Z, Zhao S (2011) Quantitative simulation of sandstone porosity evolution: A case from Yanchang Formation of Zhenjing area, Ordos Basin. Acta Petrolei Sinica 32:249-256

Paxton ST, Szabo JO, Ajdukiewicz JM (2002) Construction of an intergranular volume compaction curve for evaluating and predicting compaction and porosity loss in brittle-grain sandstone reservoirs. AAPG Bull 86:2047-2067

Reed JS, Eriksson KA, Kowalewski M (2005) Climatic, depositional and burial controls on diagenesis of Appalachian Carboniferous sandstones: qualitative and quantitative methods. Sed Geol 176:225-246

Ren D, Sun W, Qu X (2016) Characteristic of diagenesis and pore dense evolution of Chang 6 reservoir of Triassic Yanchang Formation, Ordos Basin. J Cent South Univ (Sci Technol) 47:2706-2714

Saidi F, Bernabe Y, Reuschle T (2003) The mechanical behaviour of synthetic, poorly consolidated granular rock under uniaxial compression. Tectonophys 370:105-120

Schnaid F, Prietto PDM, Consoli NC (2001) Characterization of cemented sand in triaxial compression. J Geotech Geoenviron Eng 127:857-868

Shi Z, Li X, Dong D (2018) Diagenesis and pore evolution of tight sandstone reservoir:a case study from the Upper Triassic reservoir of the southwest Sichuan basin China. Earth Sci Front 25:179-190

Spinelli GA, Mozley PS, Tobin HJ, Underwood MB, Hoffman NW, Bellew GM (2007) Diagenesis, sediment strength, and pore collapse in sediment approaching the Nankai Trough subduction zone. Geol Soc Am Bull 119:377-390

\section{Authors and Affiliations}

Taylor TR, Giles MR, Hathon LA, Diggs TN, Braunsdorf NR (2010) Sandstone diagenesis and reservoir quality prediction: models, myths, and reality. AAPG Bull 94:1093-1132

Wang Y, Shi Z, Liu Y (2011) Diagenesis of tight sandstone in the Silurian Xiaoheba Formation of the Shizhu Synclinoyium, we-stern Hubei-eastern Chongqing Area. Oil Gas Geol 32:75-82

Wang Y, Liu L, Li S et al (2017) Diagenesis and densification process of the Chang 8 Interval of Triassic Yanchang Formation western, Jiyuan area, Ordos Basin. J Palaeogeography 19:892-906

Weibel R, Friis H, Kazerouni AM, Svendsen JB, Stokkendal J (2010) Development of early diagenetic silica and quartz morphologiesexamples from the Siri Canyon Danish North Sea. Sediment Geol 228:151-170

Xi K, Cao Y, Wang Y (2015) Diagenesis and porosity-permeability evolution of low permeability reservoirs: A case study of Jurassic Sangonghe Formation in Block 1 central Junggar Basin, NW China. Pet Explor Dev 42:434-443

Yao J, Deng X, Zhao Y (2013) Characteristics of tight oil in Triassic Yanchang Formation Ordos Basin. Pet Explor Dev 40:161-169

Zhong D, Zhu H, Sun H (2013) Diagenesis and porosity evolution of sandstones in Longdong area Ordos basin. Earth Sci Front 20:61-68

Zhu G (1992) Origin and evolution and prediction of porosity in clastic reservoir rocks. Acta Sedimentol Sin 10:114-132

Zou C, Tao S, Zhou H (2008) Genesis, classification and evaluation method of diagenetic facies. Pet Explor Dev 35:526-540

Zou C, Zhu R, Wu S (2012) Types, characteristics, genesis and prospects of conventional and un-conventional hydrocarbon accumulations: Taking tight oil and tight gas in China as an instance. Acta Petrolei Sinica 33:173-187

Publisher's note Springer Nature remains neutral with regard to jurisdictional claims in published maps and institutional affiliations.

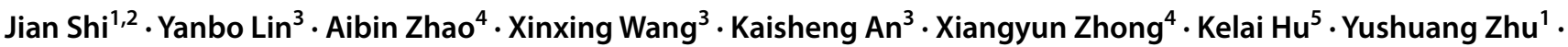 Linyu Liu ${ }^{1}$}

Jian Shi

shijian2371@163.com

Yanbo Lin

lybo_cq@petrochina.com.cn

Aibin Zhao

zab_cq@petrochina.com.cn

Xinxing Wang

121544655@qq.com

Kaisheng An

anks_cq@petrochina.com.cn

Xiangyun Zhong

zxiangy_cq@petrochina.com.cn

Kelai $\mathrm{Hu}$

hk11_cq@petrochina.com.cn
Linyu Liu

yulinliu@126.com

1 State Key Laboratory for Continental Dynamics, Department of Geology, Northwest University, Xi' an 710069, Shaanxi, China

2 Research Institute of Exploration and Development, Changqing Oilfield Company, PetroChina, Xi'an 710021, Shaanxi, China

3 No.5 Oil Production Plant, PetroChina Changqing Oilfield Company, Xi' an 710021, Shaanxi, China

4 PetroChina Changqing Oilfield Campany Oilfield Development Division, Xi'an 710021, Shaanxi, China

5 No.11 Oil Production Plant, PetroChina Changqing Oilfield Company, Xi' an 710021, Shaanxi, China 